\title{
Competence-based approach to managing staff in public administration on the basis of ontologies
}

\author{
Natalia F. Altukhova \\ Associate Professor, Head of Department of Business Informatics \\ Financial University under the Government of the Russian Federation \\ Address: 38, Scherbakovskaya Street, Moscow, 105187, Russian Federation \\ E-mail:nfaltuhova@fa.ru
}

\section{Elena V. Vasileva}

Professor, Department of Business Informatics

Financial University under the Government of the Russian Federation

Address: 38, Scherbakovskaya Street, Moscow, 105187, Russian Federation

E-mail: evvasileva@fa.ru

\section{Mariam V. Mirzoyan}

Doctoral Student, Department of Business Informatics

Financial University under the Government of the Russian Federation

Address: 38, Scherbakovskaya Street, Moscow, 105187, Russian Federation

E-mail:mvmirzoyan@fa.ru

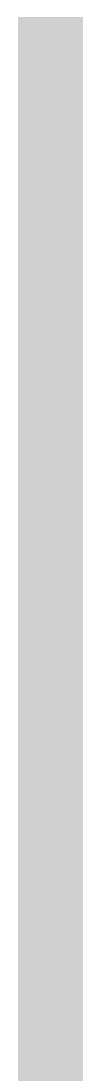

\begin{abstract}
The introduction of new management principles in public administration is in many countries linked to the introduction of client-orientation and evaluation by results. In this connection, a good deal of attention should be directed to raising the quality of work of public administration civil servants. This problem is inextricably bound with the task of raising the qualifications and competency level of workers in public administration.
\end{abstract}

In this work, we present an analysis of the current situation in management of public administrations. We distinguish between the problems of managing the competences of public servants. As part of the research, we polled more than 365 public servants from the rank of specialist to chiefs of sections. We highlighted the competences in highest demand among public servants. These are general professional skills, regulatory-legal, competences of results orientation and work efficiency. Least in demand were groups of competences such as change management, self-management and professional growth. The respondents also noted the high demand for renewal of their professional knowledge. However, there remains a problem with exchange of knowledge, when the knowledge received by employees in the best case turns up in conferences but mostly remains only for personal use and is not attached to a single carrier of information.

We present proposals for applying an ontological approach to evaluation of the competences of public servants. The set of competences makes it possible with sufficient precision to describe the work behavior which is required for successful performance of the work in the given position or in a group of similar positions. The application of ontologies makes it possible to link the task of evaluating competences through transformation of the enquiry into a set of terms and concepts with the concrete requirements of the project of the planned task or performed function. Computerization is one of the main components in the strategy for developing the public services. Creation of a system of decision 
support on the basis of mathematical methods to ensure alignment of competences of public servants with the demands made on their functions allows Human Resources to efficiently make its selection of personnel for vacancies in the public organization.

Key words: public servant, public administration, public administration efficiency, professional development, training, ontology, competence, competence-based approach.

Citation: Altukhova N.F., Vasileva E.V., Mirzoyan M.V. (2018) Competence-based approach to managing staff in public administration on the basis of ontologies. Business Informatics, no. 1 (43), pp. 17-27.

DOI: $10.17323 / 1998-0663.2018 .1 .17 .27$.

\section{Introduction}

$\mathrm{T}$ The term "public function" in legislative acts and documents is normally understood by the implementing body of executive authority to mean the activity of performing or ensuring performance of the government's powers. "Functions" in translation from Latin means the circle (area) of activity directed towards achieving a certain objective. The functions of public civil service include law enforcement, legal, legal defense, regulatory and organizational functions. Auxiliary functions of public service are intended to service the activities of public bodies. They include workflow, legal services, material-technical support.

Besides performing public functions, the activity of government bodies is also connected with providing state services. The difference between the concepts of public functions and state services comes down to highlighting the initiator of interaction of the state and society. Thus, if the initiator is a government body (for example, in the case of performing an inspection), then a public function is carried out. If the citizen or an organization addresses himself to the public administration (for example, to receive a passport, a license for some activity, etc.), then a state service is rendered to them.

Understanding the public administration in a broader sense as performance by the citizen of obligations relating to a replaced government position, we highlight three groups of functions: informational (cognitive-analytical, evaluation-expert, goal forecasting, moral-legal, documentation-archival), organizational (corporative-technological security and communicative-computer security) and technological (preparation of state decisions and their implementation, adoption and realization of administrative decisions). Thus, the public civil service can be seen as an independent form of service cum work activity performed in accordance with the competences of the public servants who ensure performance of the mandate entrusted to the state authorities [1].

\section{Analysis of the structure of the federal bodies of executive power}

In the Decree of the President of the Russian Federation dated 21 May 2012 No. 636 "The Structure of Federal Bodies of Executive Power" (version 21.07.2015) as of September 2015 there were 77 federal bodies of executive power (BEP): ministries (21 units), services (31 units) and agencies (25 units.).At the end of 2015 in state bodies, bodies of local self-rule and electoral commissions at municipal levels of Russia there were a total of $2,176,400$ people employed, which is 1.87 times more than in the year $2000^{1}$. Moreover, $86.8 \%$ of the total number of workers were engaged in bodies of executive power, $10.7 \%$ - in bodies of judicial power and prosecutors, $1.5 \%$ - in bodies of legislative power. In total at the end of 
2015 1,434,100 people were employed in federal government bodies, which, respectively is 2.75 times more than they numbered in the year 2000. Some 261,900 persons work in the state bodies of the subjects of the RF, which is 1.35 times more than in 2000. The number of employees in positions of state civil service and municipal service of the Russian Federation grew over the period 1999-2013 1.6 times (786,400 persons in 2013), including the number of workers of executive power - which grew 1.57 times $(624,035$ persons in 2013). The number of employees holding state positions and positons in the federal civil service grew 1.47 times $(564,490$ persons in 2013$)$, including employees of the executive power by 1.48 times $(442,602$ persons in 2013).

Such growth in the personnel of the public administration signifies a need to arrange stable interaction on the horizontal and vertical levels, an effective process of workflow in the subdivisions and also to reduce time expended (including on work with documents) on low productivity activities, purposeless discussions, etc.

At present, the complexity of interaction between employees of public administrations is one of the more topical problems. Among the characteristic aspects of this problem are complexity, redundancy, non-transparency and contradictions of the system of control and supervisory functions, which lead to an increase in administrative pressure and limitations which spread across the activity of organizations, in particular in the sphere of entrepreneurship. In the context of reform, there is a delimitation of these functions. Thus, the control functions (investigation, inspection, expert evaluation, analysis of primary information, etc.) overlap with supervisory functions (carrying out checks, imposing fines, licensing, issuing permits, registration, halting activity, etc.).
In this case, the function of control is to carry out tests, measurements, and expert evaluations performed by organizations accredited by the executive bodies. The supervisory functions are attached to the very bodies of executive power.

The solution of the task of simplifying administrative procedures and administrative actions is linked to the need to reduce the number of documents that must be presented by citizens and organizations for a state service, the application of new forms of documents which make it possible to eliminate multiplicity of presentation of identical information, including arranging the placement of blank applications and forms of documents on the server of the body of executive power and the development of a system for remotely providing a state service as well as reducing the number of interactions between citizens (organizations) and officials, including by use of the "single window" system. In accordance with the requirements of administrative reform, the description of administrative procedure should be included in the administrative regulations. The given description can be presented in electronic form.

At the same time, it is no less important to maintain the staff structure of public service and to adopt measures to create a personnel reserve. The requirements for professional preparation have made it possible compared to the early 2000s to secure professional staff for public service. However, the high requirements of staff structure which lowered the level and volumes of preparation of new specialists, the absence of a system of assigning graduates of the professional educational institutions have caused a shortage of professional employees at all levels, in any field and especially a shortage of directors and project managers. This underscores the importance of understanding that

${ }^{1}$ Federal Service of Statistics of Russia: http://www.gks.ru/wps/wcm/connect/ rosstat_main/rosstat/ru/statistics/state/\# 
for effective reproduction of personnel in a field it is necessary to pay attention to the conditions of preparation of personnel reserves in each sector of the economy.

In scientific research into the problems of public administration, there is mention of a high percent of turnover in personnel among civil servants, and that finding qualified replacements for them is becoming ever more complicated [2-5].

Not only in the world at large but also (for some time now) in Russia as well there is the concern over the appearance of the "revolving door syndrome" - the practice of migration of professionals between public service and business. Moreover, there arises a consequence of the move, when the civil servants lobby for the interests of those organizations where they worked before their transfer to the state institutions (the "flip-flop effect") or, the opposite, to where they recently went after leaving public service [6]. There arises a problem of security of confidential information, for example, about future plans of the government in one or another sphere, about the nature of pending orders, etc. In connection with this, for example, in Great Britain they introduced legal restrictions: those serving in the highest three grades during the two years following retirement have the right to go to work outside the state bureaucracy only with the permission of the government, while for the first two grades permission is granted on the level of a committee of advisers under the prime minister. As regards officials of lower grades, they are obliged to receive similar permission in cases when they intend to go to work for companies with which they had connections in the service, or when they had access to confidential information about the competitors to their proposed employers [6].

We note than in Russia citizens holding positions in the public administration listed in legal regulatory acts of the RF, are obliged during the two years after release from public service to communicate to their employer information about their last work place when concluding work contracts. When concluding a work contract with citizens who held positions in the public service, the employer is obliged within ten days to communicate about the conclusion of such a contract to the representative of the employer of the public servant at his last work place in the manner established by the legal regulatory acts of the Russian Federation (in accordance with article 12 of the Federal Law of the RF "On combatting corruption," art. 17, p. 3.1 of the Federal law of the RF "On the state civil service of the Russian Federation," art. 64.1 of the Labor Code of the Russian Federation). In case of potential conflict of interests, this information is reviewed in the Commission on Compliance with the Requirements of Service Conduct of Public Servants and Resolution of Conflict of Interests.

These tasks intersect with the need for development of the overall level of efficiency of the public administration and raising the qualifications competence level of employees in the state service. The problems of managing personnel, maintaining staff potential and creating a personnel reserve in public service at present are priority and critical issues [7-9]. These problems are especially acute in relation to the explosive nature of the changes which are occurring as a result of the development of Information Technologies, digital transformation of processes of organizations in all fields, computerization of society and digitalization of the economy. The development of the potential of public servants as a whole is directed towards the efficient development of the organization and its ability to adapt to the new conditions of the digital society. Under these conditions one must be certain that for realization of its strategic goals a state organization has to possess the necessary complement of personnel possessing certain qualifications and the necessary competence both in the given period of time and looking to the future. 


\section{Knowledge management in the bodies of public administration: the results of a poll}

In the process of research into the condition of information sufficiency for performance of state functions, the authors carried out a poll of public servants and employees of a number of institutions including self-governing bodies and the State Institution "Zhilishchnik" of the regions of Moscow and the Moscow Region, the prefecture of one of the districts of Moscow, the bodies of the state authorities in Penza Region, the Federal Supervisory Service in the Sphere of Health, the Department of Information Technologies in the sphere of managing state and municipal finance and ensuring information needed for the budget process at the Ministry of Finance of the Russian Federation, as well as several other state institutions.

In total, the research entailed polling more than 360 public servants occupying positions ranging from specialist to departmental directors. We analyzed variations on the organization of joint work on common tasks, control of the achievement of objectives and managing teams We determined the number of projects in which as a rule public servants participate simultaneously, the volume of urgent and non-urgent tasks solved. We reviewed the problems of excessive expenditure of working time in the period when the project was being performed, as well as the conditions of automation of administrative processes [10].

The results of the interviews confirmed the existence of common problems, including lack of clear strategy for saving knowledge and developing the competency potential of employees in the public administration.

Today the most widespread problem preventing autonomous development of the competences of employees is the problem of dissemination of knowledge among employees, including newcomers, and the further moti- vation of personnel. New knowledge received by officials in the process of training and refresher courses is not passed along to their colleagues.

Only $9.5 \%$ of the polled public servants responded that their professional knowledge is entirely adequate in their work; more than $75 \%$ were uncertain about that; and $11 \%$ of the respondents acknowledged the inadequacy of their professional knowledge. The respondents noted that the last time they were sent for training or refresher courses when choosing the topics consideration was given to the tasks which will be given to them in the organization in the future (in $46 \%$ of cases), as well as the personal characteristics of the employee $(25 \%)$. Precisely these factors were highlighted by the employees as the most significant and, consequently, the ones that should be taken into account when the directors decide about the training of their personnel. In $7 \%$ of the cases, evaluation was made of the possibility that they receive new knowledge in teaching organizations. Moreover, $17.4 \%$ of the respondents replied that they never underwent training or refresher courses.

Among the competences in greatest demand, the respondents named general professional competence $(81.9 \%)$, regulatory-legal competence $(80 \%)$, as well as competences of results orientation and work efficiency $(72.4 \%)$. The competences in least demand were "knowledge management" $(14.3 \%)$, which is not surprising insofar as business processes in state bodies are established "top down" and the working documentation of the highest levels of management often have the status of regulatory-legal documents. We also should mention the low level of demand for the group of competences around self-management and professional growth $(21.9 \%)$, which can be attributed to shortcomings of the existing competence approaches in the state structures (Table 1). 
Table 1.

Frequency of mention of groups of competences as being in greatest demand

\begin{tabular}{l|c}
\multicolumn{1}{c|}{ Groups of competences } & Frequeney \\
\hline General professional & $81.90 \%$ \\
\hline Organizational-management & $59.05 \%$ \\
\hline Informational-communicative & $60.00 \%$ \\
\hline Regulatory-legal & $80.00 \%$ \\
\hline Results-oriented and efficiency of work & $72.38 \%$ \\
\hline Project activity & $18.10 \%$ \\
\hline Change management & $14.29 \%$ \\
\hline Working in a team & $40.95 \%$ \\
\hline Self-management and professional growth & $21.90 \%$ \\
\hline Organization of workflow & $63.81 \%$ \\
\hline Ethics and behavioral culture of public & $67.62 \%$ \\
\hline servants &
\end{tabular}

In the opinion of the public servants polled, the most significant factors when selecting and promoting personnel to the top post in the organization are professional and personal qualities, as well as work experience. At the same time, authority in the group and personal desires are not given much weight. These evaluations are not in any way connected with group activity and self-development (Table 2).

Table 2.

\section{The most significant factors considered when choosing and promoting personnel to leadership positions}

\begin{tabular}{l|c}
\multicolumn{1}{c|}{ Responses } & Frequency \\
\hline Special education & $55.24 \%$ \\
\hline Personal qualities & $60.00 \%$ \\
\hline Experience of working as a specialist & $50.48 \%$ \\
\hline Experience with leadership work in public & $58.10 \%$ \\
\hline administration positions & $79.05 \%$ \\
\hline Professional qualities & $24.76 \%$ \\
\hline Authority in the group & $47.62 \%$ \\
\hline The opinion of the top managers & $22.86 \%$ \\
\hline Personal wishes &
\end{tabular}

\section{Approach to creation of a model of competences of Russian public servants}

With reference to the results of the research, one can say that for creation of a model of competences of Russian public servants it is possible to use two models of competences based on the experience of foreign countries and Russia. One of them presupposes a grouping of competences and consideration of categories of positions. In particular, as grouping of competences we can highlight general professional, organizational-management, information-communicative and other competences presented in Table 1. As categories of positions we can highlight directors, assistants (advisers), specialists and those supporting the specialists. Each group and position is juxtaposed with certain knowledge and skills [11, 12].

The merits of such a model include the direct connection with official instructions. However, in the opinion of the authors, this is what leads to the fact that the majority of groups of competences which to a greater degree are linked with effectiveness of communications and personal initiative turn out to be not in demand (below this will be confirmed by statistical data). In this connection, instead of categories of positions in the civil service it would be more correct to use the groups of positions in the civil service (higher, main, etc.). The groups and categories (art. 8 of the second chapter "Positions of the civil service" of the Federal Law dated 27 July 2004, No. 79-FZ "On the state civil service of the Russian Federation") are not hard linked with one another (Table 3), which allows the public servant to temporarily hold a higher or lower position with the same competences. Such practice to a great degree corresponds to European experience [12-14].

At present in the Ministry of Labor and Social Protection of the RF a lot of work is being carried on with respect to methodological support for qualifications requirements. In particular, there is the proposal to highlight the following 
Correspondence of groups and categories of positions of the state public servant

\begin{tabular}{l|l|l|l|l} 
& Directors & Assistants (advisers) & Specialists & Supporting specialists \\
\hline Highest positions of civil service & & & & \\
\hline Chief positions of the civil service & & & & \\
\hline Leading positions of the civil service & & & & \\
\hline Senior positions of the civil service & & & & \\
\hline Junior positions of the civil service & & & & \\
\hline
\end{tabular}

professional and personal qualities necessary for a public servant: general, applied and managerial. Precisely these qualities may be used to group competences at a high level [15].

\section{Management of competence of state public servants on the basis of the ontological approach}

Nowadays many researchers are busy with the problem of the approach to building a model of competence based on ontologies [16-18]. The application of ontologies allows us to connect the task of evaluation of competences directly with the requirements for them when fulfilling a concrete project, function, task. At the stage of preparing a request with a manager using ontology the request is transformed into a set of terms and concepts united by logical ties, such as "synonym," "homonym," "type - form," "part - whole," "association," "means for," "cause," "result."
For personal support of the leader during selection of personnel for a position from among the personnel reserve, you need a built-up system in which all information about competences, characteristics, job functions, requirements and rules for evaluation of candidates for the post are structured and formalized. The lower level of architecture of such a system [19] (Figure 1) ensures obtaining knowledge from diverse sources of structured (data bank and knowledge storage) and unstructured (documents, questionnaires) information through annotation of diverse sources of information by means of ontology, with application of computer software means of automatic extraction of information from the text and databases, the creation, merger, evaluation of quality and classification of documents by ontology.

Within the framework of this research, as a standard of the level of organization of data we selected ontology insofar as it represents a precise specification of the subject field, e.g., on

User interface (search and visualization, interaction of apps, exchange of knowledge)

\section{Presentation of data}

Requests and transfer of data (interaction with external systems and storages)

Storage of ontologies and metadata

Management of versions, access and security

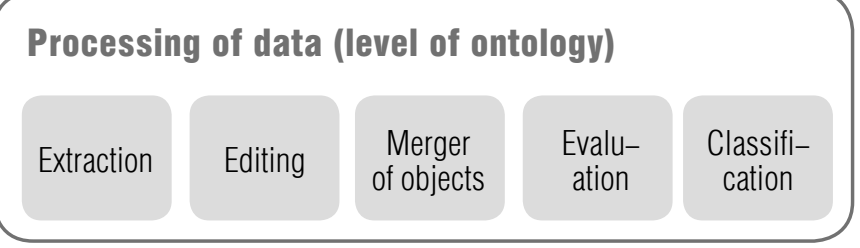

Fig 1. Architecture of a system for managing data and knowledge 
the basis of the set of metadata elements Dublin Core (DC) [20] which is built on the basis of a dictionary of terms by means of formalization of rules defining the relations between them. Ontology is a directed graph built from nodes and arcs of a graph in which is collected a full specification of the subject field, concepts, unified terms and rules for interpretation of information [20]. A visualization of ontology can be created with the help of any graphic editor, and as notation one can use the popular standard for constructing ontologies IDEF5. The elements of the ontology are exemplars (physical or abstract objects), concepts and classes (sets of objects), the attributes of objects (name, significance, etc.), relations (correlations between objects of the ontology), as well as metadata describing the form and content of documents, objects and services and establishing the connection of the level of the organization of data with levels of the system. In this way the ontology is the mechanism for organizing information using the possibility of creating subject fields, terms and connections between the terms. The formation of the ontology also allows us to create missing elements of the system content. Among the wellknown approaches to building ontologies one can name On-To-Knowledge, Methontology, CommonKADS, the languages of conceptual modeling of ontology UML and IDEF5, the formal languages for describing ontology KIF, LOOM, OWL and RDF, the means of developing ontologies - OntoEDIT, ODE, Protégé and OilEd.

The ontologies obtained and the metadata are presented with the help of the special languages OWL and RDF. At the level of presentation of the data, there is interaction with external systems and storages, management of the versions, access and storage of ontologies. At the level of the application (user interface), there can be an exchange of links to resources, support for management of data via the languages of requests (SPARQL). The ontology must react to user requests for search of the needed information via the terms and navigation in it. Thus, on the basis of the ontology a single knowledge space of the organization is formed and the risk of non-correctness of the terms used is eliminated, while the function of exchange of knowledge between employees is simplified [21-23].

In Figure 2, we present a general diagram of the level of ontology of the support system for selection of personnel to a post from the personnel reserve. When developing the given diagram we took into account publications devoted to automation of the process of search for specialists with the given set of competences by a natural language description of the required competences on the basis of applying linguistic information technologies.

On the basis of models of competences developed to describe the characteristics of public servants, an ontological model is formed of the system of support to selection of personnel for positions from the personnel reserve [24-26]. A fragment of the level of competences of the given model for the "leader" category of position is presented in Figure 3.

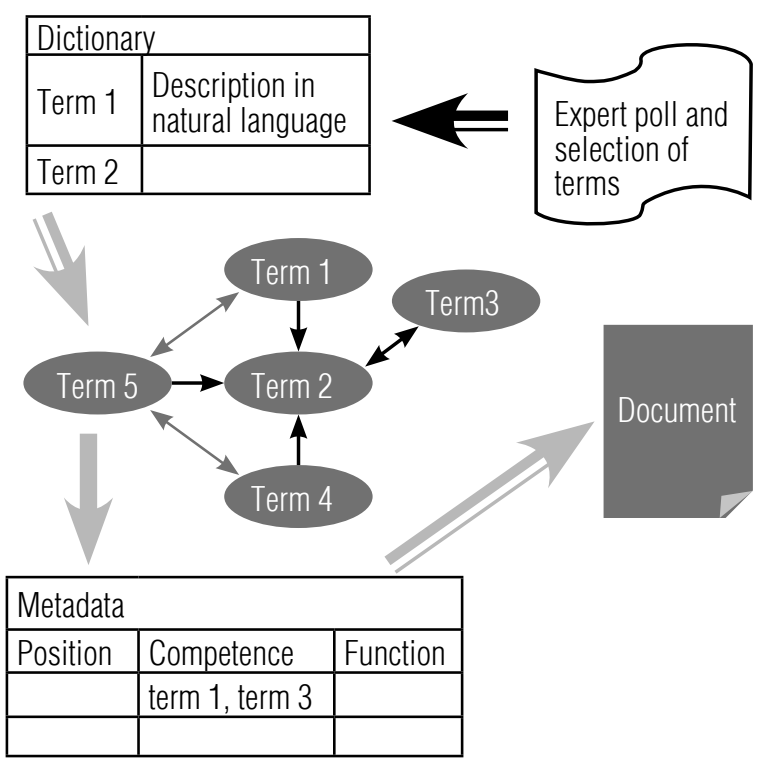

Fig. 2. Model level of the ontology of a system for evaluating the competences of public servants when selection personnel for a position 

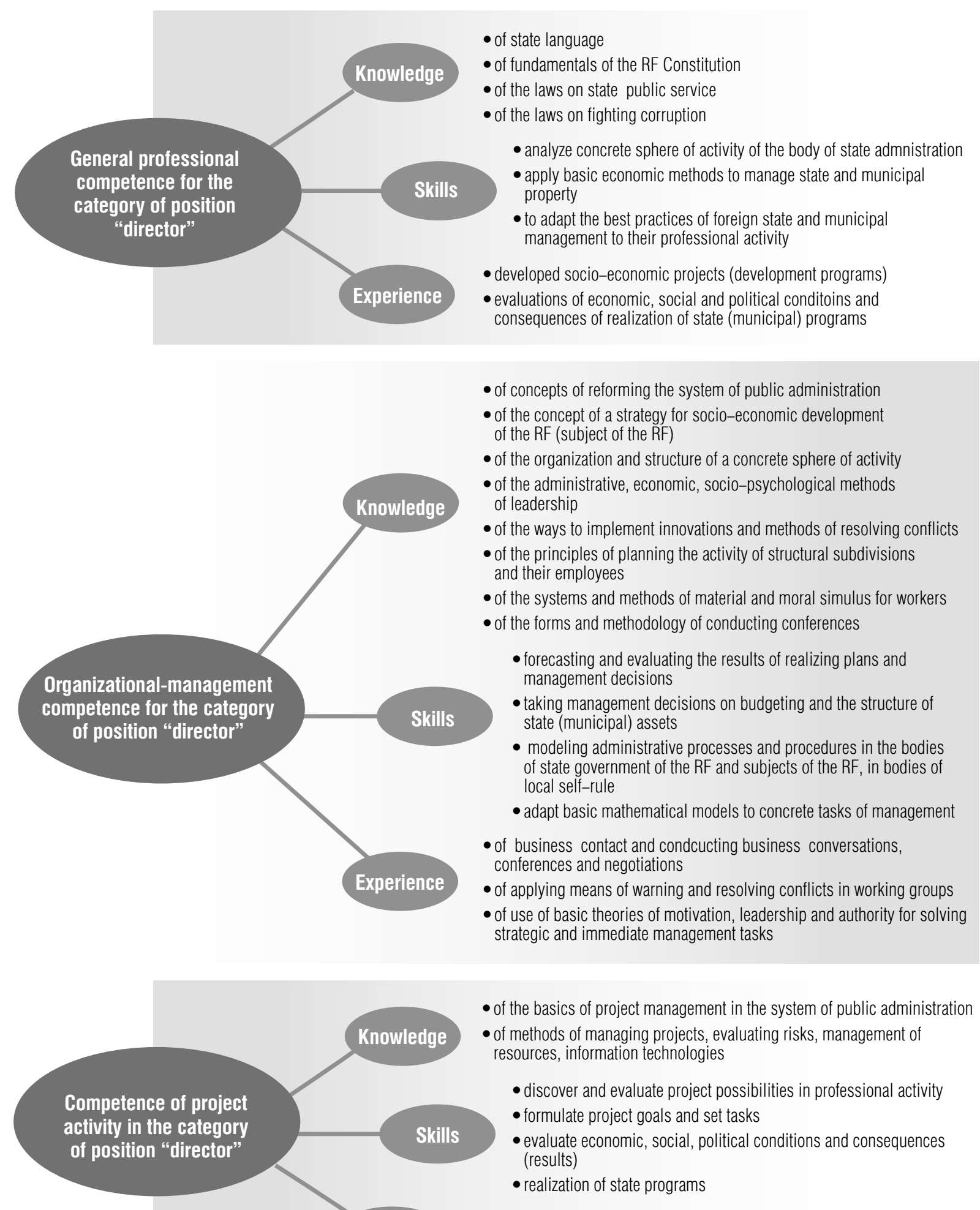

Experience developments of project documentation

- applications in practical activity of methods of managing projects

- forming and managing programs and project portfolios

Fig. 3. Level of content of general professional, organizational-management and project competences for the category of position "director" 
In order to obtain a list of criteria of basic elements of the system, it is necessary to bring in experts. It is proposed to evaluate the results of expert opinions with the help of the Delphi procedure, and to evaluate the significance of the selected criteria using the method of index grouping.

For example, if in the ontology on the structures of data are reflected the relations "type form" between the concepts "Contracts for carrying out checks" (type), "Expert opinion of documents" (form), "Inspection" (form), "Analysis of primary information" (form) and the relation "synonym" between the concepts "Personnel department" (synonym) and "HR" (synonym), then the request "What contracts are there for carrying out verifications in the organization?" will be turned into the form: "Expert evaluation of documents" and "Inspection of the object" and "Analysis of primary information," and the request "Personnel department: into the form "Personnel department" and "HR." However, this method requires a full, and at the same time simple and understandable description of the competences depending on the working situation, business process, functions carried out by the public servant, as well as a strategy for develop- ing the whole organization [16]. In the model of competence of the public servant involved in executing a certain project on fulfillment of a state function, for the information-communicative competence we highlight experience and knowledge in categories of positions, groups and categories of positions of public civil servants, as well as, depending on the concrete task, being fulfilled at the given moment in time.

\section{Conclusion}

A competence approach presupposes carrying out an evaluation of personnel by comparing results, the quality and complexity of work with standard specifications of the respective position [17]. Thus a set of competences allows us with sufficient accuracy to describe the work conduct which is required for successful performance of the job in the given position or in a group of similar positions. This set is reflected in the model of competences. At the same time, one should recall that for formation of a reserve, as a rule, it is not enough just to select employees for promotion. It is important that you correctly prepare them for the position and organize the career advancement.

\section{References}

1. Rykhlova E.A. (2014) Ponyatie, tseli i funktsii gosudarstvennoy grazhdanskoy sluzhby kak faktory, opredelyayushchie ee effektivnost', v period reformirovaniya gosudarstvennoy sluzhby [Nature, objectives and functions of the civil public administration as factors determining its efficiency, in the period of public administration reforms]. Science and Education: Property and Economy; Entrepreneurship; Law and Management, no. 4 (47), pp. 92- 99 (in Russian).

2. Haque S.M. (1998) Legitimation crisis: A challenge for public service in the next century. International Review of Administration Sciences, vol. 64, no. 1, pp. 13-26.

3. Gray A., Jenkins B. (1995) From public administration to public management: Reassessing a Revolution? Public Administration, vol. 73, no. 1, pp. 75-99.

4. Kettl D., Ingraham P., Sanders R., Horner C. (1996) Civil service reform. Building a government that works. Washington, DC: Brookings Institution.

5. Kozina M. (2010) Kadrovyy rezerv [Personnel reserve]. HR Service and Personnel, no. 3, pp. 15-18 (in Russian).

6. Obolonsky A.V. (2002) Byurokratiya dlya XXI veka? Modeli gosudarstvennoy sluzhby: Rossiya, SShA, Angliya, Avstraliya [Beurocracy for the XXI century? Models of public administration: Russia, USA, England, Australia]. Moscow: Delo (in Russian).

7. Stader J., Macintosh A. (2000) Capability modelling and knowledge management. Applications and innovations in intelligent systems (eds. R. Ellis, M. Moulton, F. Coenen). London: Springer, pp. 33-50. 
8. Biesalski E., Abecker A. (2005) Integrated processes and tools for personnel development. Proceedings of the 2005 IEEE International Technology Management Conference (ICE), Munich, Germany, 20-22 June 2005, pp. 1-8.

9. McClelland D.C. (1973) Testing for competence rather than for "intelligence". American Psychologist, vol. 28 , no. 1 , pp. 1-14.

10. Altukhova N.F., Vasileva E.V., Gromova A.A., Slavin B.B. (2016) Klyuchevye pokazateli pribornoy paneli gosudarstvennoy sluzhby [Key indicators of a dashboard of public administration]. Vestnik Universiteta (State University of Management), no. 10, pp. 10-17 (in Russian).

11. Teece D.J., Pisano G., Shuen A. (1997) Dynamic capabilities and strategic management. Strategic Management Journal, vol. 18, no. 7, pp. 509-533.

12. Lane D.C., Sterman J.D. (2011) Jay Wright Forrester. Profiles in operations research: Pioneers and innovators (eds. S. Gass, A. Assad). New York: Springer, pp. 363-386.

13. Blackman D., Connelly J., Henderson S. (2004) Does double loop learning create reliable knowledge? The Learning Organization, vol. 11, no. 1, pp. 11-27.

14. RF Ministry of Education and Science (2010) Metodika formirovaniya na konkursnoy osnove iz chisla federal'nykh gosudarstvennykh grazhdanskikh sluzhashchikh i inykh grazhdan Rossiyskoy Federatsii kadrovogo rezerva Ministerstva obrazovaniya i nauki Rossiyskoy Federatsii dlya zameshcheniya dolzhnostey federal'noy gosudarstvennoy grazhdanskoy sluzhby Rossiyskoy Federatsii [Methodic of personnel reserve formation on competitive basis from a number of federal public civil servants and other Russian Federation citizens for the RF Ministry of Education and Science, for appointing federal public civil servants posts]. Available at: https://минобрнауки.pф/state_service/227/file/471/\%D0\%A0\%D0\%B5\% D0\%B7\%D0\%B5\%D1\%80\%D0\%B2-\%D0\%BC\%D0\%B5\%D1\%82\%D0\%BE\%D0\%B4\%D0\%B8\%D0 \%BA\%D0\%B0.pdf (accessed 10 December 2015) (in Russian).

15. Kibanov A.Y. (ed.) (2017) Upravlenie personalom organizatsii [Personnel management in an organization]. Moscow: INFRA-M (in Russian).

16. Rizvanov D.A., Sen'kina G.V. (2009) Ontologicheskiy podkhod k podderzhke prinyatiya resheniy po upravleniyu kompetentsiyami organizatsii [Ontological approach to decision making in the field of organizations' competences management]. Vestnik of RSREU, no. № 4 (30), pp. $79-84$ (in Russian).

17. Blackman D., Henderson S. (2007) Being and knowing - Ontological perspectives on knowledge management systems. Electronic Journal of Knowledge Management, vol. 5, no. 3, pp. 283-290.

18. Kozlov A.N., Kozlova O.V. (2012) Otsenka kachestva obrazovaniya s ispol'zovaniem neyronnykh setey [Evaluating education quality using neural networks]. Izvestia of Samara Scientific Center of the Russian Academy of Sciences, vol. 14, no. 4 (5), pp. 1454-1456 (in Russian).

19. Mika P., Akkermans H. (2004) Towards a new synthesis of ontology technology and knowledge management. Knowledge Engineering Review, vol. 19, no. 4. pp. 317-345.

20. Borovikova O.I., Zagorul'ko Y.A. (2002) Organizatsiya portalov znaniy na osnove ontologiy [Organization of knowledge portals relying on ontologies]. Proceedings of the International Seminar "Dialog 2002. Computer-based Linguistic and Intelligent Technologies", Protvino, Russia, 31 May - 3 June 2002, vol. 2, pp. 76-82 (in Russian).

21. Staab S. (2001) Human language technologies for knowledge management. Intelligent Systems, vol. 16, no. 6, pp. 84-94.

22. Maybury M.T. (2006) Expert finding systems. MITRE Technical Report. Bedford, MA: MITRE Corp.

23. Zahlebin I.V., Fomichov V.A. (2015) Razrabotka metoda semanticheskogo poiska spetsialistov v korporativnoy baze dannykh po estestvenno-yazykovym zaprosam [Development of a method for semantic search of specialists in corporate databases using natural language queries]. Information Technologies, vol. 21, no. 5, pp. 323-331 (in Russian).

24. Kharsky K.V. (2010) Tsennostnoe upravlenie dlya biznesa [Value based management for business]. Saint Petersburg: Polytechnica-Service (in Russian).

25. Allin O.N., Salnikova N.I. (2005) Kadry dlya effektivnogo biznesa. Podbor i motivatsiya personal [Staff for efficient business. Personnel selection and motivation]. Moscow: Genesis (in Russian).

26. Ugra Administration (2014) Professional'naya model' kompetentnosti gosudarstvennykh sluzhashchikh Khanty-Mansiyskogo avtonomnogo okruga - Yugry [Professional competence model for civil servants of Khanty-Mansiysk Autonomous Okrug - Ugra. Methodical recommendations]. Khanty-Mansiysk (in Russian). 